\title{
Front Matter: Volume 9629
}

, "Front Matter: Volume 9629," Proc. SPIE 9629, Optical Systems Design 2015: Illumination Optics IV, 962901 (22 October 2015); doi:

$10.1117 / 12.2217619$

SPIE. Event: SPIE Optical Systems Design, 2015, Jena, Germany 


\title{
PROCEEDINGS OF SPIE
}

\section{Optical Systems Design 2015: Illumination Optics IV}

\author{
Tina E. Kidger \\ Stuart David \\ Editors
}

7-8 September 2015

Jena, Germany

Sponsored by

SPIE

Cooperating Organisations

European Optical Society (Finland)

Fraunhofer IOF (Germany)

Optonet (Germany)

Published by

SPIE 
The papers in this volume were part of the technical conference cited on the cover and title page. Papers were selected and subject to review by the editors and conference program committee. Some conference presentations may not be available for publication. Additional papers and presentation recordings may be available online in the SPIE Digital Library at SPIEDigitallibrary.org.

The papers reflect the work and thoughts of the authors and are published herein as submitted. The publisher is not responsible for the validity of the information or for any outcomes resulting from reliance thereon.

Please use the following format to cite material from these proceedings:

Author(s), "Title of Paper," in Optical Systems Design 2015: Illumination Optics IV, edited by Tina E. Kidger, Stuart David, Proceedings of SPIE Vol. 9629 (SPIE, Bellingham, WA, 2015) Six-digit Article CID Number.

ISSN: 0277-786X

ISSN: 1996-756X (electronic)

ISBN: 9781628418187

Published by

SPIE

P.O. Box 10, Bellingham, Washington 98227-0010 USA

Telephone +1 3606763290 (Pacific Time) · Fax +1 3606471445

SPIE.org

Copyright (C) 2015, Society of Photo-Optical Instrumentation Engineers.

Copying of material in this book for internal or personal use, or for the internal or personal use of specific clients, beyond the fair use provisions granted by the U.S. Copyright Law is authorized by SPIE subject to payment of copying fees. The Transactional Reporting Service base fee for this volume is $\$ 18.00$ per article (or portion thereof), which should be paid directly to the Copyright Clearance Center (CCC), 222 Rosewood Drive, Danvers, MA 01923. Payment may also be made electronically through CCC Online at copyright.com. Other copying for republication, resale, advertising or promotion, or any form of systematic or multiple reproduction of any material in this book is prohibited except with permission in writing from the publisher. The CCC fee code is 0277-786X/15/\$18.00.

Printed in the United States of America.

Publication of record for individual papers is online in the SPIE Digital Library.

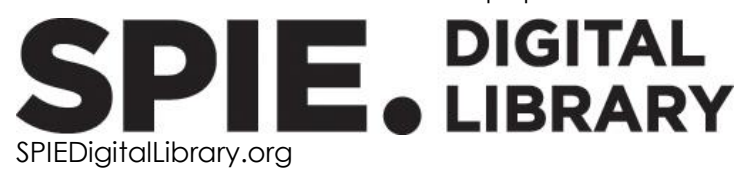

Paper Numbering: Proceedings of SPIE follow an e-First publication model, with papers published first online and then in print. Papers are published as they are submitted and meet publication criteria. A unique citation identifier (CID) number is assigned to each article at the time of the first publication. Utilization of CIDs allows articles to be fully citable as soon as they are published online, and connects the same identifier to all online, print, and electronic versions of the publication. SPIE uses a six-digit CID article numbering system in which:

- The first four digits correspond to the SPIE volume number.

- The last two digits indicate publication order within the volume using a Base 36 numbering system employing both numerals and letters. These two-number sets start with 00, 01, 02, 03, 04, $05,06,07,08,09,0 A, 0 B \ldots$ OZ, followed by $10-1 Z, 20-2 Z$, etc.

The CID Number appears on each page of the manuscript. The complete citation is used on the first page, and an abbreviated version on subsequent pages. 


\title{
Contents
}

\author{
$\checkmark$ Authors \\ vii Conference Committee \\ ix Introduction \\ xiii Diffractive optical elements made from photonic metamaterials (Plenary Paper) [9626-502]
}

\section{SESSION 1 ILLUMINATION APPLICATIONS}

962902 Optical design of static and dynamic laser beam shaping systems (Invited Paper) [9629-1]

962903 Optical design of precision approach path indicators in a portable runway lighting system [9629-2]

962904 A cross-polarized freeform illumination design for glare reduction in fruit quality inspection [9629-3]

962905 Freeform étendue-preserving optics for light and color mixing [9629-4]

\section{SESSION 2 OPTICAL MODELLING I}

962906 TIR collimator designs based on point source and extended source methods [9629-5]

962907 Practical optical design of an LED collimator [9629-6]

962908 Design of reflector focusing light flux from LED into arbitrary 3D curve [9629-7]

962909 Freeform array projection [9629-8]

\section{SESSION 3 FREEFORM TECHNIQUES}

9629 OC Design of freeform aplanatic systems [9629-11]

9629 OE Algorithm for freeform construction using non-ideal light sources [9629-13]

SESSION 4 TRENDS IN AUTOMOTIVE LIGHTING

9629 OG Matrix light and pixel light: optical system architecture and requirements to the light source [9629-15] 
9629 01 Design method for automotive high-beam LED optics [9629-17]

SESSION 5 OPTICAL MODELLING II

9629 OK Simulation of white LEDs with a planar luminescent layer using the extended addingdoubling method [9629-19]

9629 OM From BRDF to roughness: defining the link between two key parameters for optical design [9629-21]

962900 Design of diffractive optical surfaces within the nonimaging SMS design method [9629-23]

9629 OP Fluorescence and multilayer structure of the scorpion cuticle [9629-24]

$96290 Q$ Steerable patterned OLED backlight for autostereoscopic display application [9629-25] 


\section{Authors}

Numbers in the index correspond to the last two digits of the six-digit citation identifier (CID) article numbering system used in Proceedings of SPIE. The first four digits reflect the volume number. Base 36 numbering is employed for the last two digits and indicates the order of articles within the volume. Numbers start with 00, 01, 02, 03, 04, 05, 06, 07, 08, 09, 0A, 0B...0Z, followed by 10-1Z, 20-2Z, etc.

Andreev, Evgeny S., 08

Benítez, Pablo, 05, 0C, 00

Borisova, Ksenya $\mathrm{V} ., 08$

Bräuer, A., 09, 0E

Byzov, Egor $V_{\text {., }}$ Ol

Chaves, Julio, 05, 0C

Chen, YU-Jen, OP

Chipman, Russel, 04

Chiu, Pei-Ju, OP

Cvetkovic, Aleksandra, 05

Dick, L., OE

Doskolovich, Leonid L., Ol

Duerr, Fabian, 02, 05

Falkner, Matthias, xiii

Fasold, Stefan, xiii

Fehse, Karsten, $0 Q$

Grabovickic, D., OC

Gross, H., 09

Hanselaer, Peter, OK

Herkommer, A., 06

Hernández, Maikel, 05

Hild, Olaf, $0 Q$

Infante, J., OC

Kazanskiy, Nikolay L., Ol

Keresztes, Janos C., 04

Knobbe, Jens, $0 Q$

Koshel, R. John, 04

Kravchenko, Sergey V., 08

Kuperman-Le Bihan, Quentin, OM

Lee, Cheng-Chung, OP

Leyre, Sven, OK

Li, Chen, 09, 0E

Mendes-Lopes, João, 00

Menzel, Christoph, xiii

Meuret, Youri, OK

Michaelis, D., 09, OE

Miñano, Juan C., 05, 0C, 00

Mohedano, Rubén, 05

Moiseev, Mikhail A., 08, 0l

Monaghan, Adam, 03

Narasimhan, B., OC

Nikolic, Milena, OC

Pertsch, Thomas, xiii

Rehn, H., 07

Richter, Bernd, $0 Q$

Rockstuhl, Carsten, xiii

Ryckaert, Jana, OK

Saeys, Wouter, 04

Scholles, Michael, $0 Q$
Schreiber, P., 09, 0E

Sorgato, Simone, 05

Spinger, Benno, 0G

Staude, Isabelle, xiii

Stover, John C., 04

Talpur, T., 06

Thienpont, Hugo, 02, 05

Timinger, Andreas L., OG

Vogel, Uwe, OQ

Walker, Duncan J. W., 03

Walther, Benny, xiii

Wartenberg, Philipp, $0 Q$ 
Proc. of SPIE Vol. $9629962901-6$

Downloaded From: https://www.spiedigitallibrary.org/conference-proceedings-of-spie on 26 Apr 2023 Terms of Use: https://www.spiedigitallibrary.org/terms-of-use 


\title{
Conference Committee
}

\author{
Symposium Chair \\ Wilhelm Ulrich, Carl Zeiss AG (Germany) \\ Symposium Co-chairs \\ Juan Carlos Miñano, Universidad Politénica de Madrid (Spain) \\ David M. Williamson, Nikon Research Corporation of America \\ (United States) \\ Honorary Symposium Chair \\ Tina Kidger, Kidger Optics Associates (United Kingdom) \\ Conference Chairs \\ Tina E. Kidger, Kidger Optics Associates (United Kingdom) \\ Stuart David, Synopsys, Inc. (United States) \\ Conference Programme Committee \\ Pablo Benitez, Universidad Politécnica de Madrid (Spain) \\ Peter Brick, OSRAM Opto Semiconductors GmbH (Germany) \\ William Cassarly, Synopsys, Inc. (United States) \\ R. John Koshel, College of Optical Sciences, The University of Arizona \\ (United States) \\ Juan Minano, Universidad Politécnica de Madrid (Spain) \\ Julius A. Muschaweck, ARRI Inc. (Germany) \\ Jannick P. Rolland, University of Rochester (United States) \\ Andreas L. Timinger, Philips Technologie GmbH (Germany)
}

\section{Session Chairs}

1 Illumination Applications

Stuart David, Synopsys, Inc. (United States)

2 Optical Modelling I

Julius A. Muschaweck, ARRI Inc. (Germany)

3 Freeform Techniques

Juan Carlos Miñano, Universidad Politécnica de Madrid (Spain) 
4 Trends in Automotive Lighting

Peter Brick, OSRAM Opto Semiconductors GmbH (Germany)

5 Optical Modelling II

Duncan J. W. Walker, Walker Optics, Ltd. (United Kingdom) 


\section{Introduction}

SPIE's fourth European Illumination Optics conference maintained its previous high standards. The conference was composed of five sessions with a total of twenty four papers presented.

Session 1 - Illumination Applications

Session 1 opens with an invited paper explaining the use of the analytic description of the optical design problem by means of functional differential equations. It is shown that this analytic design method can also be used to solve dynamic optical system problems. A following paper presents an optical design for Precision Approach Path Indicators (PAPIs) in a portable runway lighting system requiring high efficiency and compactness. The advent of LEDs as viable lighting sources offers the opportunity for significantly improved wall-plug efficiency of these lighting systems. Two more papers in this session cover a crosspolarized freeform illumination design for glare reduction in fruit quality inspection, and freeform étendue-preserving optics for light and color mixing.

\section{Session 2 - Optical Modelling I}

This session includes four papers beginning with a paper on TIR collimator designs based on point source and extended source methods. The second paper discusses the practical optical design of an LED collimator. Thirdly, the problem of focusing light flux into an arbitrary curve in 3D space using a numerical-analytical approach to design a reflective surface, which efficiently produces the prescribed intensity distribution on the arbitrary 3D curve is addressed. Lastly, micro-freeform array projection is discussed, where the freeform surfaces are designed by a generalized approach of Cartesian Oval representation. Different designs for different illumination tasks (smooth illumination distributions, sharp features), are discussed with the possible implementation of laser lithographic manufacture.

\section{Session 3 - Freeform Techniques}

The session opens with an invited paper on freeform surface shape tradeoffs in illumination design. The paper examines some of the common tradeoffs with special emphasis on how the shape of the freeform surfaces change to meet changing performance requirements. This is followed by a paper on freeform aplanatic systems. The author reviews the fact that axisymmetric aplanatic systems have been used in the past for condensers and concentrators. It is then shown that a rigorous solution to the general non-symmetric problem using 
freeform technology requires three free form surfaces obtained from a solution of a system of partial differential equations.

The final paper discusses a mapping algorithm for freeform construction using non-ideal light sources. Consideration is also given to freeform designs for clusters of LED-sources.

Session 4 - Trends in Automotive Lighting

An invited paper discusses many new ways that light can be controlled and enhanced for the driver of a modern car. Next is a discussion of the use of matrix light and pixel light arrays in the optical system architecture of automotive light sources. Following is a design discussion of laser based headlights. Blue laser diodes pump a phosphor converter to emit bright white light from an extremely small area, which then facilitates very compact headlight designs potentially revolutionizing automotive forward lighting. The use of multiple single laser diodes, phosphor conversion, and color mixing are also considered. Continuing on is a discussion of design methods for automotive high beam LED optics. Finally, an invited paper covers practical aspects of automotive lighting design. It is proposed that 'innovative design' and 'best practices of optics design and lighting development' need to merge at all stages in Computer Assisted Lighting $(\mathrm{CAL})$ to run efficient development cycles. This need presents a very practical challenge to engineering management in accomplishing optical design and development projects.

\section{Session 5 - Optical Modelling II}

The first two papers in this session discuss different solutions using white LEDs and modelling of LEDs by combining ray and wave-optical approaches. The third paper discusses the potential modeling relationship between 'roughness' and the Bidirectional Scatter Distribution Function (BSDF). Results showed a link between roughness and BSDF, with the strength of the link somewhat wavelength dependent, which can be useful for communication between optical designers using BSDF terminology and manufacturers using roughness terminology. Continuing is a presentation of examples of the usage of high luminance LED's, i.e. above $100 \mathrm{Mnits}$, which have been developed following on the achievement of full-LED headlamps. The unique subject of the luminescence of the scorpion cuticle is explored followed by a presentation on steerable patterned OLED backlighting for autostereoscopic displays.

In summary, as evidenced from the proceedings of this 4th SPIE European illumination optics conference, we are continuing to find new ways to model, manipulate, and control light for the benefit of all. Our illumination optics community, a relatively small and expert community, is pushing forward the 
frontiers of optical illumination science and technology. This present conference, along with past conferences, has added significantly to the improvements in optical illumination through the communication of developments and the personal interactions that occur with the face-to-face contact that is a large part of our conference format. The success of our conference is a fitting and permanent contribution to this, "The International Year of Light."

Tina E. Kidger Stuart David 
Proc. of SPIE Vol. 9629 962901-12

Downloaded From: https://www.spiedigitallibrary.org/conference-proceedings-of-spie on 26 Apr 2023 Terms of Use: https://www.spiedigitallibrary.org/terms-of-use 